RESIDENT

\& FELLOW

SECTION

Section Editor

Mitchell S.V. Elkind,

MD, MS

R.S. Cetlin, MD

G.R. Rodrigues, MD

M.A. Pena-Pereira, MD

D.S. Oliveira, MD

C.P. Souza, MD

V. Tumas, MD, PhD

Address correspondence and reprint requests to Dr. Vitor Tumas, Department of

Neurosciences and Behavior Sciences, Ribeirão Preto School of Medicine-University of São Paulo, Campus Universitário Monte Alegre, Ribeirão Preto-SP, Brazil 14048-900 tumasv@rnp.fmrp.usp.br
Supplemental data at www.neurology.org

\section{Teaching Video NeuroImages: \\ Excessive grinning in Wilson disease}

自
(A, B) Excessive grinning, (C) Kayser-Fleischer ring, (D) "face of giant panda" sign and basal ganglia $\mathrm{T} 2$ hyperintensity
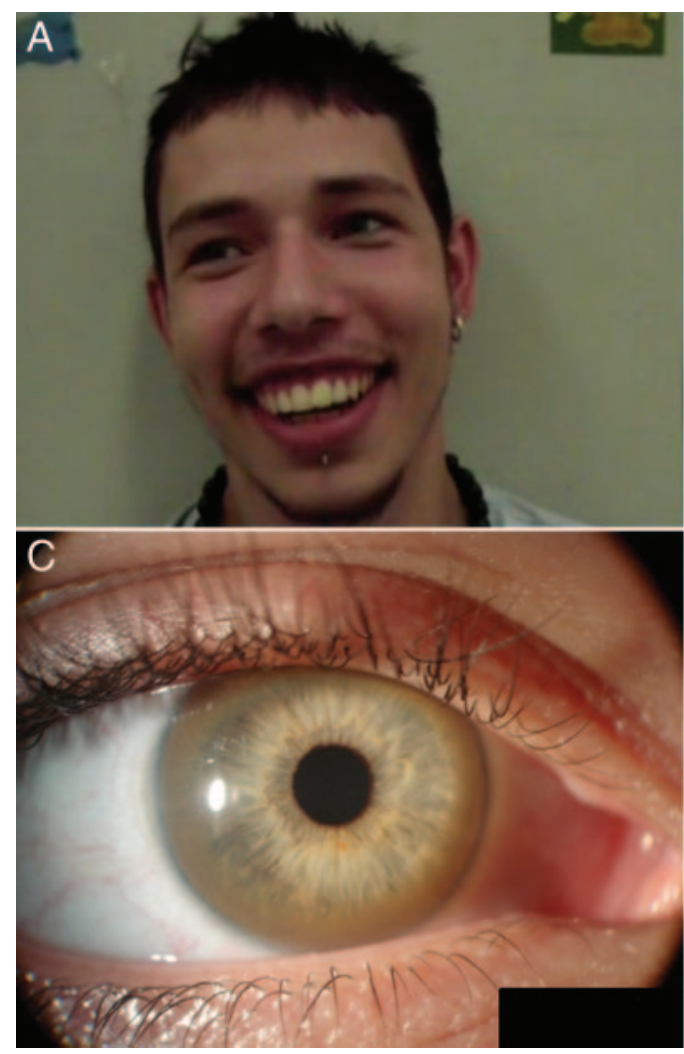

A 19-year-old man presented with a 3-month history of excessive grinning. Examination revealed unrestrained grinning and mild symmetric parkinsonism. Wilson disease was suspected and confirmed by the presence of Kayser-Fleischer ring (figure), suggestive brain MRI (figure), low ceruloplasmin, and high urinary copper levels.

Wilson disease is a disorder of copper metabolism characterized by hepatic impairment and movement disorders. Typical facial manifestations, although not pathognomonic, include excessive grinning, in which the patient grins to trivial stimuli, ${ }^{1}$ as demonstrated in this report; sustained open-mouth smile, when a par-
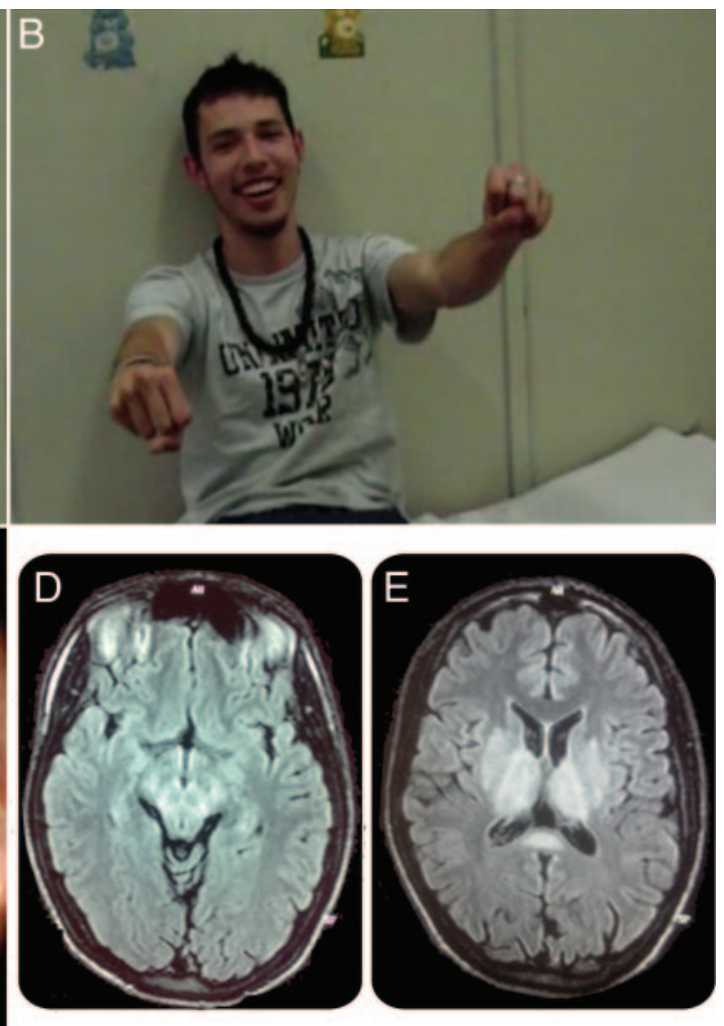

kinsonian face is associated with a dystonic dropped jaw (sometimes referred to as "vacuous smile")2; and fixed forced smile, when facial dystonia produces a sustained spasm of risorius and zygomaticus muscles (also referred to as "risus sardonicus").

\section{REFERENCES}

1. Wilson SAK. Progressive lenticular degeneration (hepatolenticular degeneration, Wilson's disease). In: Ninian-Bruce A, ed. Neurology. Baltimore: Williams \& Wilkins; 1954:941-967.

2. Das SK, Ray K. Wilson's disease: an update. Nat Clin Pract Neurol 2006;2:482-493.

From the Department of Neuroscience (R.S.C., M.A.P.-P., D.S.O., V.T.) and Movement Disorders Clinic (G.R.R., C.P.S.), School of Medicine of Ribeirao Preto, University of Sao Paulo, Brazil.

Disclosure: The authors report no disclosures. 


\section{Neurology}

\section{Teaching Video NeuroImages: Excessive grinning in Wilson disease}

R. S. Cetlin, G. R. Rodrigues, M. A. Pena-Pereira, et al.

Neurology 2009;73; e73

DOI 10.1212/WNL.0b013e3181bacef0

\section{This information is current as of October 5,2009}

\section{Updated Information \&}

Services

Supplementary Material

References

Subspecialty Collections

Permissions \& Licensing

Reprints including high resolution figures, can be found at: http://n.neurology.org/content/73/14/e73.full

Supplementary material can be found at: http://n.neurology.org/content/suppl/2009/10/04/73.14.e73.DC1

This article cites 1 articles, 0 of which you can access for free at: http://n.neurology.org/content/73/14/e73.full\#ref-list-1

This article, along with others on similar topics, appears in the following collection(s):

Dystonia

http://n.neurology.org/cgi/collection/dystonia

MRI

http://n.neurology.org/cgi/collection/mri

Parkinson's disease/Parkinsonism

http://n.neurology.org/cgi/collection/parkinsons_disease_parkinsonism

Information about reproducing this article in parts (figures,tables) or in its entirety can be found online at:

http://www.neurology.org/about/about_the_journal\#permissions

Information about ordering reprints can be found online: http://n.neurology.org/subscribers/advertise

Neurology ${ }^{\circledR}$ is the official journal of the American Academy of Neurology. Published continuously since 1951, it is now a weekly with 48 issues per year. Copyright . All rights reserved. Print ISSN: 0028-3878. Online ISSN: 1526-632X.

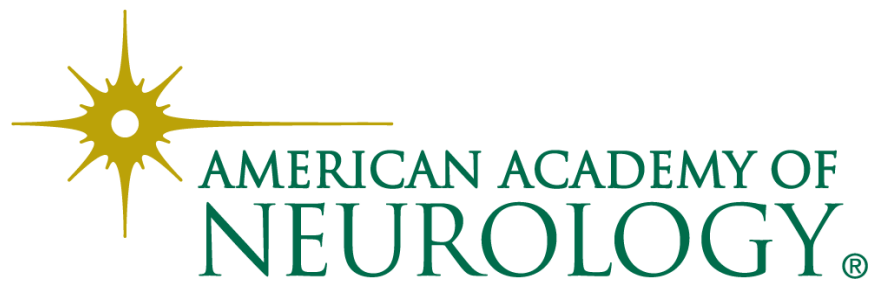

